\title{
Enhancing Students Learning Outcomes and Creative Thinking Skills in Computer Numeric Control Subject Using Project-Based Learning Model
}

\author{
${ }^{1}$ Elly Rahmawati*,2Supari Muslim, ${ }^{3}$ Soeryanto, ${ }^{4}$ Tri Rijanto \\ Email : ${ }^{1}$ ellyrahmawati16070895028@mhs.unesa.ac.id*, 22suparimuslim@unesa.ac.id, \\ 3soeryanto@unesa.ac.id, 4tririjanto@unesa.ac.id \\ *: coresponndensing author \\ 1 Technology and Vocational Education Study Program, Postgraduate, State University of Surabaya; \\ 2,4Electrical Engineering, Faculty of Engineering, State University of Surabaya; \\ ${ }^{3}$ Mechanical Engineering, Faculty of Engineering, State University of Surabaya.
}

Article history

Received Sep 26, 2021

Revised Nov 29,2021

Accepted Nov 30, 2021

Keywords

Project-based learning

Creative thinking

Learning outcomes

Computer numeric control
This study aimed to determine the effect of project-based learning on student learning outcomes and creative thinking skills in computer numeric control subjects at SMK KAL-1 Surabaya. This study used a quasi-experimental factorial research design with a 2-way ANOVA test technique. In this study, 66 students from class XI of the Mechanical Engineering Expertise Program were divided into experimental groups $(n=33)$ and a control group $(n=33)$. The instrument used in this research is in the form of test sheets and observations to measure the level of student's creative thinking and their learning outcomes. This study found that student learning outcomes using project-based learning are significantly higher than students who taught using direct learning models in computer numeric control subjects. Furthermore, the learning outcomes of students who have a high level of creative thinking are significantly higher than those of students who have a low level of creative thinking. Moreover, there is an interaction between using learning models and creative thinking on three domains of learning outcomes (cognitive, affective, and psychomotor) in computer numeric control subjects.

This is an open access article under the CC-BY-SA license.

\section{Introduction}

In the 21st century, the national education system faces complex challenges in preparing quality human resources that compete globally. Special skills are needed to answer these challenges: learning and innovation (Trilling \& Fadel, 2009), which includes creating new ideas and developing creative ideas (Bishop, 2011). The government has made efforts to make improvements and improve the quality of education at various types and levels of education (Trianto, 2009). The development of the 2013 curriculum is part of the strategy in improving the quality of education. The theme of curriculum development 2013 is a curriculum that can produce Indonesian people 
who are productive, creative, innovative, and effective through strengthening integrated attitudes, skills, and knowledge (Kemendikbud, 2014). In other words, students are expected to be at the level of describing something and develop, implement, and convey new ideas to others and be open and responsive to new and different perspectives (Guilford, 1976).

However, according to Artini (2019), earning so far in schools tends to transfer knowledge completely from the teacher's mind to the student's mind. Hence, the teacher is more active than the student. Students are also less trained in finding their knowledge, so their interest and attention tend to decrease in learning, which impacts low learning outcomes. It is in line with interviews conducted with students and teachers of Machining Engineering skill competencies at SMK KAL-1 Surabaya. In computer numeric control subject, there are several obstacles include: (1) the direct learning is still often used so that learning seems only one way; (2) there are still many students who do not understand the subject matter; (3) students' interest and motivation to learn is low; and (4) lack of creativity and cooperation among students in groups. It is also shown from student learning outcomes in the odd semester of the 2019/2020 academic year, where around 65\% of students have not achieved the minimum completeness criteria value. Thus, teachers need to find ways to help students learn effectively to encourage their learning and innovation skills to produce work contextually. In this case, the project-based learning model is considered suitable to be applied by teachers in learning.

The project-based learning model uses problems as the first step in collecting and integrating new knowledge based on students' experiences in real activities (Garza, 2016). Project-based learning is a learning model that uses projects or activities as the core of learning. Students explore, assess, interpret, synthesize, and provide information to produce various forms of learning outcomes (Kemendikbud, 2014). Several previous research results found that project-based learning can improve student learning outcomes, as well as their soft skills and hard skills (AlHabbah \& Suparji, 2015; Cedeño et al., 2018; Sudjimat, 2016) especially creativity (Artini, 2019; Fatmawati, 2011). Another research is Ghaleb, Almalki, \& Aly (2020), which investigates the effectiveness of project-based learning as a teaching technique for robotics courses using real robot projects. The results of Ghaleb et al's research found that project-based learning functions as an effective active learning tool in improving student learning outcomes and motivating them to study and research further in the field of robotics. Therefore, project-based learning models are expected to create interactions between students that make learning active, fun, and motivated so that learning objectives are achieved, and most importantly, can make students think creatively (Abidin, 2013).

Nevertheless, creative thinking is a student's skill to connect, analyze and evaluate in generating abstract ideas into practical ideas to create a value or quality of his work (Brookhart, 2010). 
Through creative thinking skills, students can direct themselves, detail ideas, analyze ideas and the quality of personal work, and create new ideas in problem-solving. In computer numeric control subjects, creative thinking skills are needed to solve problems that will be faced in the learning process of making programs on the worksheet. The project-based learning model will be used as a learning model for computer numeric control subjects with the hope that student learning outcomes and creative thinking skills can be improved. In addition to the application of the projectbased learning model used in the learning process in the classroom, creative thinking skills are also measured to determine the learning outcomes of each student. Therefore, this research aims to analyze (1) the differences in learning outcomes for students who learn using a project-based learning model than those who learn using direct learning models; (2) the differences in learning outcomes for students with a high level of creative thinking than students with a low level of creative thinking; and (3) the interaction between learning models and the level of creative thinking on learning outcomes.

\section{Project-Based Learning}

According to Sani (2014), project-based learning (PjBL) is a teaching and learning strategy involving students working on a worthwhile project to solve contextual problems or problems in everyday life. The emergence of the project-based learning model originated from a constructivist view that refers to contextual learning. This learning model is seen as a form of open-ended contextual activity-based learning, which is part of the learning process that strongly emphasizes problem-solving as a collaborative effort carried out in the learning process in a certain period (Sanjaya, 2007). The syntax steps in the classroom that apply project-based learning are as follows: (1) presenting the basic question and starting with an investigation; (2) preparing plans, determining the schedule and rules for project work; (3) compiling a project work schedule from the beginning to the completion of the project; (4) monitoring the progress of project work and helping students who have difficulties; (5) testing the program with the Mach 3 turn application before the program is inserted into the machine until it becomes a finished product workpiece and conducts an assessment from the planning stage to the result presentation stage; and (6) evaluate the product according to the standardized job sheet and dimensions and reflect on the investigation and processes (Kemendikbud, 2014).

\section{Direct Learning Model}

Direct learning is a learning model specifically designed to develop student learning about procedural and declarative knowledge that is well structured and learned step by step (Amri \& Ahmadi, 2010). Direct learning emphasizes learning dominated by the teacher to play an important and dominant role in the learning process (Nur, 2011). According to Eggen \& Kauchak (2012), the essence of direct learning is that the teacher first explains and exemplifies the process, then asks 
students to practice according to what has been explained previously by the teacher and gives feedback. The process repeats until students can apply the skills and can practice independently. The direct learning model applied to the control class is an approach that teaches basic skills where the lessons are very goal-oriented (Cohen, 2008). The learning environment is structured from preparing and motivating students, explaining or demonstrating, guided exercises, feedback, and follow-up exercises (Nur, 2011).

\section{Creative Thinking}

Creative thinking is the level of a person's ability to give birth to a new idea, either in the form of ideas or real works that are relatively different from those that have existed before (Brookhart, 2010). Something new here does not have to be a new result even though it may appear as something new, but it can be the result of developing or combining two or more existing concepts (Nadjafikhah \& Yaftian, 2013). Munandar (2014) explained that creative potential could be measured using direct or indirect tests, and in the form of writing or pictures made by the subject. Indicators of creative thinking are fluent thinking skills, flexible thinking skills, original thinking skills, and elaborating skills (Ghufron \& Suminta, 2014).

\section{Learning Outcomes}

Student learning outcomes are essentially changes in behaviour due to learning in a broader sense covering the cognitive, affective, and psychomotor fields (Sudjana, 2011). Cognitive learning outcomes are students' ability to build their information and knowledge in learning materials, which are measured using test instruments (Sanjaya, 2007). The learning outcomes of the affective domain are the character values of behavior possessed by each student, which include spiritual and social values (Ibrahim, 2010), measured by using an attitude observation sheet. Meanwhile, learning outcomes in the psychomotor domain of students' technical abilities, physical motor skills refer to the ability to use tools and complete work procedures during the learning process and are measured using performance test instruments (Muslim, 2013; Ratumanan, 2001).

\section{Method}

This type of research uses a quasi-experimental factorial research design (Sugiyono, 2013), which aims to determine the differences in learning outcomes in the project-based learning model and creative thinking in numerical control computer subjects. The subjects in this study were students of class XI of the Mechanical Engineering Expertise Program at SMK KAL-1 Surabaya for the 2020/2021 academic year, totaling 66 students. The subjects were divided into two different groups. A first group is an experimental group involved in learning using project-based learning, namely class XI TpmA, with 33 students. In comparison, the other 33 students came from class XI TPmB as a control group involved in learning using the direct learning model. 
The research instrument is in the form of test sheets and observations. The test is used to measure the level of student creative thinking skills and cognitive learning outcomes. Meanwhile, observation is used to measure the psychomotor and affective aspects of students during learning. However, validity and reliability tests were conducted before the learning tools, and research instrument was used. The validity and reliability test results indicate that the instrument is valid and feasible to use for research data collection. The analysis prerequisite test used homogeneity, normality and linearity tests. Furthermore, the data obtained were analyzed by using a 2-way ANOVA test (Sugiyono, 2013).

\section{Result and Discussion}

\section{The Differences in Learning Outcomes for Students Who Learn Using A Project-Based Learning Model than Those Who Learn Using Direct Learning Models}

Based on the results of the analysis of the two-way variance data in Table 1., it is known that there are significant differences in learning outcomes between the experimental group and the control group in the cognitive domain ( $\mathrm{F}=51.819, \mathrm{p}<.00)$, affective domain $(\mathrm{F}=49.613, \mathrm{p}<.00)$, and psychomotor domain $(\mathrm{F}=.739, \mathrm{p}<.039)$. These results indicated that student learning outcomes in the experimental group taught using project-based learning were significantly higher than the control group taught using direct learning.

Table 1. ANOVA Test Results on the Three Domain of Learning Outcomes

\begin{tabular}{lccccc}
\hline \multicolumn{1}{c}{ Domain } & $\begin{array}{c}\text { Type III Sum of } \\
\text { Squares }\end{array}$ & df & Mean Square & $\boldsymbol{F}$ & Sig \\
\hline Cognitive & 404.580 & 1 & 404.580 & 51.819 & .000 \\
Affective & 60.365 & 1 & 60.365 & 49.613 & .000 \\
Psychomotor & 1.338 & 1 & 1.338 & .739 & .039 \\
\hline
\end{tabular}

In addition, the mean score in Table 2. below shows that the average score of the group taught by project-based learning (cognitive= 89.607; affective $=86.429$; psychomotor $=81.673$ ) showed a better score than the group taught with direct learning (cognitive= 84.653; affective $=84.169$; psychomotor $=81.564)$. In other words, there was a difference in learning outcomes between the experimental and control groups.

Table 2. Mean Test Results on Learning Outcomes in terms of Learning Model

\begin{tabular}{|c|c|c|c|c|c|}
\hline Domain & $\begin{array}{c}\text { Learning } \\
\text { model }\end{array}$ & Mean & Std. Error & $\begin{array}{r}95 \% \text { Confic } \\
\text { Lower Bound }\end{array}$ & $\begin{array}{l}\text { cce interval } \\
\text { Upper Bound }\end{array}$ \\
\hline \multirow{2}{*}{ Cognitive } & PjBL & 89.607 & .487 & 88.634 & 90.579 \\
\hline & $\mathrm{DL}$ & 84.653 & .487 & 83.680 & 85.625 \\
\hline \multirow{2}{*}{ Affective } & PjBL & 86.429 & 196 & 86.037 & 86.820 \\
\hline & DL & 84.169 & 194 & 83.782 & 84.557 \\
\hline \multirow{2}{*}{ Psychomotor } & PjBL & 81.673 & .218 & 81.237 & 82.109 \\
\hline & DL & 81.564 & .218 & 81.128 & 82.001 \\
\hline
\end{tabular}


The Differences in Learning Outcomes for Students with A High Level of Creative Thinking than Students with A Low Level of Creative Thinking

The results of the analysis of the two-way variance data in Table 2., it is known that there are significant differences in learning outcomes between the experimental group and the control group in the cognitive domain $(\mathrm{F}=.563, \mathrm{p}<.034)$, affective domain $(\mathrm{F}=.300, \mathrm{p}<.045)$, and psychomotor domain $(\mathrm{F}=1.475, \mathrm{p}<.029)$. These results indicate that the average value of students who have a high level of creative thinking is higher than students who have a low level of creative thinking on learning outcomes (cognitive, affective, and psychomotor domains).

Table 3. ANOVA Test Results for Learning Outcomes of Students with High and Low Level Creative Thinking

\begin{tabular}{lccccc}
\hline \multicolumn{1}{c}{ Domain } & $\begin{array}{c}\text { Type III Sum of } \\
\text { Squares }\end{array}$ & $\boldsymbol{d f}$ & Mean Square & $\boldsymbol{F}$ & Sig \\
\hline Cognitive & 4.398 & 1 & 4.398 & .563 & .034 \\
Affective & .365 & 1 & .365 & .300 & .045 \\
Psychomotor & 2.672 & 1 & 2.672 & 1.475 & .029 \\
\hline
\end{tabular}

The results of the mean scores in Table 4. also show differences in learning outcomes between students who have high levels of creative thinking and those who have low levels of creative thinking. It can be seen from the average score of students who have a high level of creative thinking (cognitive $=87.388$; affective $=85.304$; psychomotor $=81.829)$ which shows a better score than the group that has a low level of creative thinking (cognitive $=86.871$; affective $=85.294$; psychomotor $=$ 81.408).

Table 4. Mean Test Results on Learning Outcomes in terms of Creative Thinking

\begin{tabular}{llcccc}
\hline \multicolumn{1}{c}{ Domain } & $\begin{array}{c}\text { Level of Creative } \\
\text { Thinking }\end{array}$ & Mean & Std. Error & $\begin{array}{c}\text { 95\% Confidence interval } \\
\text { Lower Bound }\end{array}$ \\
& Upper Bound \\
\hline \multirow{2}{*}{ Cognitive } & Low & 86.871 & .487 & 85.899 & 87.844 \\
\multirow{2}{*}{ Affective } & How & 87.388 & .487 & 86.415 & 88.361 \\
& High & 85.294 & .186 & 84.923 & 85.666 \\
\multirow{2}{*}{ Psychomotor } & Low & 85.304 & .204 & 84.896 & 85.711 \\
& High & 81.408 & .218 & 80.972 & 81.844 \\
\hline
\end{tabular}

The Interaction between Learning Models and the Level of Creative Thinking on Learning Outcomes

The analysis of variance presented in Table 5. shows an interaction between the use of learning models and the level of student's creative thinking on learning outcomes (cognitive, affective, and psychomotor domains). This can be seen from the acquisition of the $\mathrm{F}$ value index on learning outcomes in the cognitive domain $(\mathrm{F}=117,083, \mathrm{p}<.00)$, affective domain $(\mathrm{F}=97,990, \mathrm{p}<.00)$ and psychomotor domain $(F=90,649, \mathrm{p}<.00)$ in each experimental group and control group.

Table 5. ANOVA Test Results on Learning Outcomes on the Influence of Learning Models and Creative Thinking 
JOVES Vol.4 No.2, November 2021, p.131-142

\begin{tabular}{lccccc}
\hline \multicolumn{1}{c}{ Domain } & $\begin{array}{c}\text { Type III Sum of } \\
\text { Squares }\end{array}$ & $\boldsymbol{d} \boldsymbol{f}$ & Mean Square & $\boldsymbol{F}$ & Sig \\
\hline Cognitive & 914.138 & 1 & 914.138 & 117.083 & .000 \\
Affective & 119.227 & 1 & 119.227 & 97.990 & .000 \\
Psychomotor & 164.221 & 1 & 164.221 & 90.649 & .000 \\
\hline
\end{tabular}

Besides, the mean test results in Table 6. show a mutually influencing interaction between project-based learning, direct learning, and the level of creative thinking on learning outcomes. It can be seen from the acquisition of the average score of each experimental group and control group on the three domains of learning outcomes (cognitive, affective, and psychomotor).

Table 6. Mean Test Results for Three Domains of Learning Outcomes in terms of Learning Models and Creative Thinking

\begin{tabular}{|c|c|c|c|c|c|c|}
\hline \multirow[b]{2}{*}{ Domain } & \multirow{2}{*}{$\begin{array}{l}\text { Level of } \\
\text { Creative } \\
\text { Thinking }\end{array}$} & \multirow[b]{2}{*}{$\begin{array}{l}\text { Learning } \\
\text { Model }\end{array}$} & \multirow[b]{2}{*}{ Mean } & \multirow[b]{2}{*}{ Std. Error } & \multicolumn{2}{|c|}{ 95\% Confidence interval } \\
\hline & & & & & $\begin{array}{l}\text { Lower } \\
\text { Bound }\end{array}$ & $\begin{array}{l}\text { Upper } \\
\text { Bound }\end{array}$ \\
\hline \multirow{4}{*}{ Cognitive } & \multirow{2}{*}{ Low } & PjBL & 85.625 & .699 & 84.229 & 87.021 \\
\hline & & $\mathrm{DL}$ & 88.118 & .678 & 86.763 & 89.472 \\
\hline & \multirow{2}{*}{ High } & PjBL & 93.588 & .678 & 92.234 & 94.943 \\
\hline & & DL & 81.188 & 699 & 79.791 & 82.584 \\
\hline \multirow{4}{*}{ Affectve } & \multirow{2}{*}{ Low } & PjBL & 85.000 & .255 & 84.489 & 85.511 \\
\hline & & $\mathrm{DL}$ & 85.588 & .270 & 85.049 & 86.128 \\
\hline & \multirow{2}{*}{ High } & PjBL & 87.857 & .298 & 87.262 & 88.452 \\
\hline & & DL & 82.750 & .278 & 82.194 & 83.306 \\
\hline \multirow{4}{*}{ Psychomotor } & \multirow{2}{*}{ Low } & PjBL & 79.875 & .313 & 79.249 & 80.501 \\
\hline & & MPL & 82.941 & .304 & 82.334 & 83.549 \\
\hline & \multirow{2}{*}{ High } & PjBL & 83.471 & .304 & 82.863 & 84.078 \\
\hline & & MPL & 80.188 & .313 & 79.561 & 80.814 \\
\hline
\end{tabular}

This study found that student learning outcomes in the experimental group whose projectbased learning implementation was significantly higher than the control group using the direct learning model. The results of this study are consistent with Candra et al. (2019) and Yosar (2019), who revealed that project-based learning impacted increasing student learning outcomes. In computer numerical control subjects, project-based learning models present authentic problems to students to construct their knowledge and develop higher skills and inquiry. Students became active in participating in the learning process, which increases their learning outcomes. In line with Muryanti (2015), project-based learning can provide many benefits when applied in learning. Project-based learning contains complex tasks based on challenging problems that lead students to design, solve problems, make decisions, carry out investigative activities, and work independently or in groups (Kusumaningrum \& Djukri, 2016; Nurhayati \& Harianti, 2015). Project-based learning can improve student learning outcomes, accompanied by increased learning behaviour and student responses to learning (Khoirunisa, Sunarya, \& Rahdiyanta, 2020). The quality of the learning process carried out also increases successfully (Al-Habbah \& Suparji, 2015; Cedeño et al., 2018; Sudjimat, 2016). Thus in this study, the application of project-based learning has been proven to improve student learning outcomes in the cognitive, affective or psychomotor domains. 
The present study also found that there are differences in the achievement of learning outcomes (cognitive, affective, and psychomotor) in students who have a high level of creative thinking compared to students who have a low level of creative thinking. Project-based learning applies to learning that stimulates students' creative and critical thinking in project and productoriented situations. In line with Rachmawati et al. (2018) who found that students' scientific, creative thinking skills and critical scientific thinking increased in the moderate category after project-based learning was carried out. In addition, students who have high creative thinking skills get higher learning outcomes than students who have low creative thinking abilities. It means that the effect of the project-based learning model on the computer numerical control subject learning outcomes is also highly dependent on the level of student's creative thinking. Project-based learning encourages students to construct knowledge and skills personally. The existence of opportunities to convey ideas, listen to other people's ideas, and reflect on their ideas on the ideas of others, is a form of knowledge empowerment experience (Mulhayatiah, 2014).

In contrast to project-based learning, the direct learning model involves much one-way communication. Students who have a higher level of creative thinking will find it difficult to develop their social and interpersonal skills because they have few opportunities to be actively involved (Trianto, 2007). In addition, learning that is more dominant with the lecture method will make students feel bored quickly on the learning material (Widaningsih, 2010). Meanwhile, direct learning is more effective if applied to teach explicit concepts and skills to students whose low thinking abilities (Trianto, 2007). However, the project-based learning model helps students complete problems in learning that are directly related to real everyday life through creative thinking skills (Fajri \& Wahyuni, 2016). Creative thinking is characterized by students producing bright, unique, and interesting ideas in solving a problem. The findings in this study are supported by previous research that states that the project-based learning model affects students' creative thinking abilities (Artini, 2019; Fajri \& Wahyuni, 2016; Fatmawati, 2011).

Furthermore, this present study found that there is an interaction between using the learning models and creative thinking on three domains of learning outcomes (cognitive, affective, and psychomotor) in computer numeric control subjects. It means that in learning which uses a projectbased learning model for students with high creative thinking skills, they get higher learning outcomes than students with low creative thinking abilities. This study result are in line with Mulhayatiah (2014) which show that the application of project-based learning model affects student's creative thinking skill and their learning outcomes. The project-based learning model is better than the direct instruction learning model, especially in developing students' creativity in learning (Eliza et al., 2017). Project-based learning made students achieved a deeper development of knowledge and teamwork (Cedeño et al., 2018). In line with Santyasa (2012) who stated that 
learning carried out using a project-based learning model can foster students' efforts to build complex and experiential memory representations and show a strong level of connection between semantic, episodic, and action knowledge.

In their particular action to produce a product, students in project-based learning are also active periodically, involving the physical, mental, and all senses related to the learning process (Artini, 2019). Thus, project-based learning can create a more interesting and meaningful learning experience for students while the teacher only acts as a facilitator and mediator. But it should be noted that not all active and project-involved learning activities can be referred to as project-based learning. The characteristics of the appropriate material if applied in the project-based learning model include having basic competencies that emphasize the skills or knowledge aspects at the level of application, analysis, synthesis, and evaluation. In addition, it can also produce a product and relate to real problems or in accordance with everyday life (Kemendikbud, 2014). The teacher must guide students towards the goals established in the dialogue between student interests and curriculum goals and then lead group activities, which is a form of joint work in the project-based learning method (Postholm, 2015). However, teachers can use project-based learning when they want to develop students' creative thinking skills in designing and making projects that can be used to solve problems systematically, so that this model can develop higher-order thinking skills in implementing learning (Nurhayati \& Harianti, 2015).

\section{Conclusion}

The purpose of this study was to determine the effect of the application of project-based learning to enhance student's learning outcomes and creative thinking skills in the computer numeric control subject at SMK KAL-1 Surabaya. The findings of this study indicate that student learning outcomes using project-based learning are significantly higher than students who taught using direct learning models in computer numeric control subjects. Furthermore, the learning outcomes of students who have a high level of creative thinking are significantly higher than those of students who have a low level of creative thinking. Moreover, there is an interaction between using learning models (project-based learning and direct learning) and creative thinking on three domains of learning outcomes (cognitive, affective, and psychomotor) in computer numeric control subjects. So, it can be concluded that the application of project-based learning in computer numerical control subjects is very helpful in increasing student's creative thinking and learning outcomes. Given the many benefits derived from implementing project-based learning in computer numerical control subjects, teachers should consider applying project-based learning models to other subjects while still adjusting the characteristics of the learning materials. Thus, with the application of project-based learning, students will become more active, creative, independent and responsible in following each stage of learning in the classroom. 


\section{References}

Abidin, Y. (2013). Pembelajaran Berbasis Pendidikan Karakter. Bandung: Refika Aditama.

Al-Habbah, A. M., \& Suparji. (2015). Penerapan Strategi Pembelajaran Berbasis Proyek (project Based Learning) pada Mata Pelajaran Pelaksanaan Konstruksi Kayu Siswa Kelas XII TKY di SMK Negeri 1 Sidoarjo. Jurnal Teknik Pembangunan, 2(2), 42-52.

Amri, S., \& Ahmadi, I. K. (2010). Proses Pembelajaran Kreatif dan Inovatif dalam Kelas: Metode, Landasan Teoritis-Praktis dan Penerapannya. Jakarta: PT. Prestasi Pustakaraya.

Artini, N. P. J. (2019). Pengaruh Model Pembelajaran Berbasis Proyek Terhadap Keterampilan Berpikir Kreatif Siswa pada Mata Pelajaran IPA. Jurnal Kajian Pendidikan Widya Accarya FKIP Universitas Dwijendra, (2085-0018).

Bishop, J. (2011). Partnership for 21st century skills.

Brookhart, S. M. (2010). How to Assess Higher-Order Thinking Skills in Your Classroom. Alexandria: ASCD.

Candra, R. A., Prasetya, A. T., \& Hartati, R. (2019). Analisis Kemampuan Berpikir Kreatif Peserta Didik Melalui Penerapan Blended Project Based Learning. Jurnal Inovasi Pendidikan Kimia, 13(2), 2437-2446.

Cedeño, E. A. L., Rocha - Hoyos, J. C., Zurita, D. B. P., Gómez, J. M., \& Ortega, S. C. (2018). Project-Based Learning Case of Study Education in Automotive Mechanical Engineering. Revista Espacios, $39(25), 10$.

Cohen, M. T. (2008). The Effect of Direct Instruction Versus Discovery Learning on The Understanding of Science Lessons by Second Grade Students. In NERA Conference Proceedings 2008 (p. 30). Retrieved from https://opencommons.uconn.edu/nera_2008/30

Eggen, P. D., \& Kauchak, D. (2012). Strategi dan Model Pembelajaran. Jakarta: Index.

Eliza, F., Syamsuarnis, S., Myori, D. E., \& Hamdani, H. (2017). Pembelajaran Berbasis Proyek pada Mata Diklat Instalasi Penerangan Listrik Bangunan Sederhana. INVOTEK: Jurnal Inovasi Vokasional Dan Teknologi, 17(1), 1-10. https://doi.org/10.24036/invotek.v17i1.13

Fajri, N., \& Wahyuni, D. (2016). Pengaruh Model Pembelajaran Berbasis Proyek Terhadap Kemampuan Berpikir Kreatif Siswa. COCOS BIO-Jurnal Biologi dan Pembelajaran Biologi, 1(2), 35-41.

Fatmawati, B. (2011). Pembelajaran Berbasis Proyek Untuk Meningkatkan Keterampilan Berpikir Kreatif Mahasiswa. Jurnal Pengajaran MIPA, 16(2), 85-92. https://doi.org/10.33627/oz.v $7 \mathrm{i} 2.6$

Ghaleb, N. M., Almalki, H. M., \& Aly, A. A. (2020). Project-Based Learning of Robotics for Engineering 
Education Improvement. International Journal of Mechanical and Production Engineering Research and Development, 10 (3), 4395-4424. https://doi.org/10.24247/ijmperdjun2020 418

Ghufron, M. N., \& Suminta, R. R. (2014). Gaya Belajar Kajian Teoritik. Yogyakarta: Pustaka Pelajar. Guilford, J. P. (1976). Fundamental Statistics in Psychology and Education (Third edit). Tokyo: Mc.Graw Hill.

Ibrahim, M. (2010). Dasar-Dasar Proses Belajar Mengajar. Surabaya: Universitas Negeri Surabaya. Kemendikbud. (2014). Materi Pelatihan Implementasi Kurikulum 2013. Jakarta: Badan Pengembangan Sumber Daya Manusia Pendidikan dan Kebudayaan dan Penjaminan Mutu Pendidikan Kementerian Pendidikan dan Kebudayaan. https://doi.org/10.31219/osf.io/dp $79 n$

Khoirunisa, A. Z., Sunarya, I. K., \& Rahdiyanta, D. (2020). Dampak Implementasi Model Pembelajaran Project-Work Berbasis Karakter Terhadap Sikap dan Prestasi Belajar Mahasiswa. Jurnal Dinamika Vokasional Teknik Mesin, 5(1), 57-68. https://doi.org/10.21831 /dinamika.v5i1.30996

Kusumaningrum, S., \& Djukri, D. (2016). Pengembangan Perangkat Pembelajaran Model Project Based Learning (PJBL) untuk Meningkatkan Keterampilan Proses Sains dan Kreativitas. Jurnal Inovasi Pendidikan IPA, 2(2), 241. https://doi.org/10.21831/jipi.v2i2.5557

Maria, A., \& Garza, A. M. E. D. de la. (2016). Using Project Work in Alternative Assessment. In $A$ Guidebook for Assessing Learning (pp. 141-149). Mexico: Primera Edición.

Mulhayatiah, D. (2014). Penerapan Model Pembelajaran Berbasis Proyek untuk Meningkatkan Kemampuat Berpikir Kreatif Mahasiswa. Edusains, VI(01), 18-22.

Munandar, U. (2014). Pengembangan Kreativitas Anak Berbakat. Jakarta: Rineka Cipta.

Muryanti, V. (2015). Project-Based Assessment Models for Senior High School Grade XI. Indonesian Journal of English Language Studies, 1(2), 183-206.

Muslim, S. (2013). Tes Kinerja (Performen Test) dalam Bidang Pendidikan Teknologi dan Kejuruan. In Seminar Elektro dan Pendidikan Elektro. Surabaya.

Nadjafikhah, M., \& Yaftian, N. Y. (2013). The Frontage of Creativity and Mathematical Creativity. Procedia - Social and Behavioral Sciences, 90, 344-350. https://doi.org/10.1016/j.sbspro. 2013.07.101

Nur, M. (2011). Pengajaran Langsung. Surabaya: Pusat Sains dan Matematika sekolah UNESA.

Nurhayati, A. S., \& Harianti, D. (2015). Model Pembelajaran Project Based learning (pjbl) (Vol. 151). Retrieved from https://sibatik.kemdikbud.go.id/inovatif/assets/file_upload/pengantar/pdf/ 
pengantar_5.pdf

Postholm, M. B. (2015). Classroom Management in Project Work. Creative Education, 06(19), 20772089. https://doi.org/10.4236/ce.2015.619212

Rachmawati, I., Feranie, S., Sinaga, P., \& Saepuzaman, D. (2018). Penerapan Pembelajaran Berbasis Proyek untuk Meningkatkan Keterampilan Berpikir Kreatif Ilmiah dan Berpikir Kritis Ilmiah Siswa SMA Pada Materi Kesetimbangan Benda Tegar. WaPFi (Wahana Pendidikan Fisika), 3(2), 25. https://doi.org/10.17509/wapfi.v3i2.13725

Ratumanan, T. G. (2001). Belajar dan Pembelajaran. Semarang: Univercity Press.

Sani, A. (2014). Pembelajaran Saintifik untuk Implementasi Kurikulum 2013. Jakarta: Bumi Aksara.

Sanjaya, W. (2007). Strategi Pembelajaran Berorientasi Standar Proses Pendidikan. Jakarta: Kencana Prenanda Media.

Santyasa, I. W. (2012). Pembelajaran Inovatif. Singaraja: Universitas Pendidikan Ganesha.

Sudjana, N. (2011). Penilaian Hasil Proses Belajar Mengajar. Bandung: PT Remaja Rosdakarya.

Sudjimat, D. A. (2016). Implementation of Project Based Learning Model in Mechanical Machining Skills Package of Vocational High School. AIP Conference Proceedings, 1778(Imeeec), 1-7. https://doi.org/10.1063/1.4965758

Sugiyono. (2013). Metodologi Penelitian Kuantitatif Kualitatif R\&D. Bandung: Alphabeta.

Trianto. (2007). Model-model Pembelajaran Inovatif Berorientasi Konstruktivistik. Jakarta: Prestasi Pustaka.

Trianto. (2009). Mendesain Model Pembelajaran Inovatif-Progresif. Jakarta: Kencana Prenanda media.

Trilling, B., \& Fadel, C. (2009). 21st Century Skills: Learning for Life in Our Times. John Wiley \& Sons. Widaningsih, D. (2010). Perencanaan Pembelajaran Matematika. Bandung: Rizqi Press.

Yosar, Y. (2019). Penerapan Model PJBL (Projeck Based Learning) untuk Meningkatkan Hasil Belajar Peserta Didik pada Mata Pelajaran Teknik Pemesinan .... Universitas Negeri Makassar. Retrieved from http://eprints.unm.ac.id/15287/ 